\title{
USER GUIDE
}

To enhance your ability to recall the vocabulary and to pronounce it correctly, this book is accompanied by audio recordings and audio-visual e-Flashcards of the entire contents of each chapter, recorded in both English and Arabic. This e-Learning material is provided in two formats: 1. Audio recordings compatible with iPods and other devices (via MP3 files on the $\mathrm{CD}$ accompanying this book and via http://www.euppublishing.com/page/emev/e-learning);

2. Audio-visual e-Flashcards (via http://www. euppublishing.com/page/emev/e-learning). Material on the website requires access token 44919Di.

\section{Audio recordings}

Main features

- Each Arabic term is recorded with authentic native pronunciation at normal speed.

- Each Arabic term is preceded by its equivalent in English.

- Each chapter is recorded as a single MP3 track (the track numbers correspond to the chapter numbers, e.g. Track 01 = Chapter 1 ).

- The audio files can be played on a computer or transferred to an MP3 device (e.g. iPod, mobile phone, etc.), enabling you to study on the move.

\section{Tips}

- Make sure that you engage actively with the audio recordings by repeating each Arabic term during the pause. 
- Pause the recording and challenge yourself to produce the Arabic word before it is announced.

\section{Audio-visual e-Flashcards}

Main features

- Designed with the language-learning software Before You Know It (BYKI), available as a free download suitable for Windows or Mac at www.byki.com/fls (select 'Arabic' as your chosen language).

- Each e-Flashcard contains the English term on one side and the Arabic on the reverse.

- Each term is recorded in Arabic and English at normal speed.

- Both sounds (English and Arabic) can be slowed down for paced listening.

- Vocabulary acquisition is accelerated through a variety of fun interactive self-assessment activities.

\section{Tips}

Keep track of your progress through BYKI's interactive self-assessment modes:

- Preview it: learn and review the vocabulary in e-Flashcard mode including audio, without being assessed.

- Recognise it: test your recognition of the vocabulary in English from the Arabic side, and vice versa.

- Produce it: test your knowledge of the vocabulary in English by typing its translation in Arabic, and vice versa. 
viii • USER GUIDE

\section{Download}

The Internet Arabic BYKI sets are available at http://www.euppublishing.com/page/emev/e-learning using access code 44919Di. For more information about BYKI, go to www.byki.com. 